\title{
Intrapopulational chromosome number variation in Zephyranthes sylvatica Baker (Amaryllidaceae: Hippeastreae) from Northeast Brazil
}

\author{
WINSTON J. P. FELIX ${ }^{1}$, JULIE H. A. DUTILH ${ }^{2}$, NATONIEL F. DE MELO ${ }^{3}$, \\ ANDREA A. FERNANDES ${ }^{1}$ and LEONARDO P. FELIX ${ }^{1}$
}

(received: August 10, 2006; accepted: May 15, 2008)

\begin{abstract}
Intrapopulational chromosome number variation in Zephyranthes sylvatica Baker (Amaryllidaceae: Hippeastreae) from Northeast Brazil). Zephyranthes Herb. is a taxonomically complex and cytologically variable group, with about 65 species of Neotropical distribution. Chromosome number variability in 32 individuals of a Zephyranthes sylvatica population from Northeast Brazil was investigated. Three cytotypes were found: $2 n=12$ (one metacentric, four submetacentric and one acrocentric pairs), in 24 individuals; $2 n=12+1 \mathrm{~B}$, in five and three individuals with $2 n=18$, a triploid cytotype. All diploid individuals showed chromosomes with polymorphism in pair one and two, while in triploids this polymorphism was observed in all chromosome triplets, generally with two homomorphic chromosomes and a higher or lower heteromorphic chromosome. All individuals had reticulated interfasic nucleus and a slightly asymmetric chromosome complement, with one metacentric chromosome pair and the others more submetacentric to acrocentric. These data confirm the cytological variability previously registered for the genus. Mechanisms involved in karyotypic evolution in this population are discussed.
\end{abstract}

Key words - Amaryllidaceae, B chromosomes, chromosome variability, triploid, Zephyranthes

RESUMO - (Variação cromossômica numérica intrapopulacional em Zephyranthes sylvatica Baker (Amaryllidaceae: Hippeastreae) no Nordeste do Brasil). O gênero Zephyranthes Herb. é um grupo taxonômicamente complexo e cariologicamente variável, compreende cerca de 65 espécies de distribuição predominantemente neotropical. O presente trabalho aborda a variabilidade cariológica em um total de 32 indivíduos de Z. sylvatica obtidas em uma única população do Nordeste do Brasil. Todos os indivíduos apresentaram núcleo interfásico reticulado e complemento cromossômico bimodal, pela ocorrência de um par cromossômico metacêntrico e os demais submetacêntricos. Foram observados três citotipos: $2 n=12$ (um par metacêntrico, quatro submetacêntricos e um acrocêntricos) em 24 indivíduos; $2 n=12+1 \mathrm{~B}$, em cinco, além de um citotipo triplóide com $2 n=18$ em três indivíduos. Todos os citotipos diplóides exibiram polimorfismo cromossômico para os pares um e dois, enquanto nos triplóides esse mesmo polimorfismo foi observado nas trincas correspondente aos pares cromossômicos diplóides, geralmente com dois cromossomos homórficos e um cromossomo heteromórfico maior que os dois anteriores. Esses dados confirmam a variabilidade cariológica anteriormente registrada para o gênero. São discutidos os mecanismos de evolução cariotípica envolvidos nessa variabilidade.

Palavras-chave - Amaryllidaceae, cromossomo B, triplóide, variação cromossômica, Zephyranthes

\section{Introduction}

The genus Zephyranthes Herb. comprises about 65 species of Neotropical distribution (Hutchinson 1959, Judd et al. 1999), with chromosome records for about fifty of them (Greizerstein \& Naranjo 1987). The genus is a karyologically variable group, with records from

1. Universidade Federal da Paraíba, Centro de Ciências Agrárias, Departamento de Fitotecnia, 58397-000, Areia PB, Brazil.

2. Universidade Estadual de Campinas, Departamento de Botânica, Instituto de Biologia, Caixa Postal 6109, 13084-971, Campinas SP, Brazil.

3. Embrapa Semi-árido, BR 428, Km 152, Caixa Postal 23, 56302970 Petrolina PE, Brazil

4. Corresponding author: winstonpessoa@yahoo.com.br
$2 n=10$ chromosomes in Zephyranthes seubertii E. P. Hume (Daviña 2001) up to $2 n=72+1 \mathrm{~B}$ in $Z$. chlorozolen D. Dietr. (Greizerstein \& Naranjo 1987), over $2 n=100$ in Z. arenicola T.S. Brandeg. and $2 n=c a$. 200, in an interespecific horticultural hybrid (Flory \& Smith 1980a). The variation chromosome number observed in Zephyranthes suggests three possible base numbers: $\mathrm{x}=$ 5, 6 and 7 (Naranjo 1974, Daviña \& Fernández 1989).

The most of species shows karyotype formed by one or few long metacentric pairs and other clearly smaller chromosomes with sub median, sub terminal and terminal centromeres (Flory 1977). In several species of Zephyranthes, chromosome polymorphisms due to structural (Raina \& Khoshoo 1970) and numerical alterations as aneuploidy, disploidy and polyploidy 
(Daviña \& Fernandez 1989) and, occurrence of supernumerary chromosomes, (Greizerstein \& Naranjo 1987, Guerra 2000) were already reported.

Zephyranthes is a taxonomically complex genus and for many authors is subdivided in two genera: Zephyranthes s.s., with more actinomorphic flowers and erect stamens, and Habranthus Herb. with more zygomorphic flowers with declined stamens. This division however, is not a natural one, as confirmed by Arroyo (1981) with anatomical data and Meerow et al. (2000a, b) with a phylogenetic morphological analysis, rDNA segments and geographical distribution data. As a result Zephyranthes is considered sensu latu (Habranthus included) in this work.

There are about 36 species of Zephyranthes s.1. collected in Brazil, of which only 14 are karyologically known, with only one record, of $2 n=12+1 \mathrm{~B}$ in $Z$. franciscana Herb. ex Baker, known for Northeast Brazil (Guerra 2000). Previous observations not systematic in some individuals of this species indicated the occurrence of chromosome number variation among individuals in a population of $Z$. sylvatica at Petrolina, state of Pernambuco, Northeast Brazil, in the "caatinga" (semi-arid vegetation). The occurrence of intra-specific numerical chromosome variation, although frequent in cultivated species of Zephyranthes (Raina \& Khoshoo 1970), and in different populations (Daviña 2001), has not been much recorded for a same population. In Argentina, intrapopulational records of $2 n=38,39$ in Z. candida Herb. (Naranjo 1969) showed an extra chromosome morphologically similar to another pair and was interpreted as trisomy, while $2 n=20,21$ in Z. minima Herb. (Naranjo 1974), showed a morphologically different extra chromosome that was interpreted as a B chromosome.

In plants from Northeast Brazilian occurrence of intraspecific chromosome number variation has not been reported. In 44 species of Cymbidioide phyllad and terrestrial orchids (Felix \& Guerra 2000, 2005) or in subfamily Aurantioideae of the Rutaceae, for example (Guerra et al. 2000), no intraspecific chromosome number variation was observed. In this region numerical chromosome variation has been observed as polyploidy in many related species, as genus Emilia of the Asteraceae (Guerra \& Nogueira 1990) or in isolated geographic races of Passiflora misera H. B. \& K. (Melo et al. 2001). But none variation of chromosome number has been reported in Zephyranthes or any other monocotyledons species.

The present investigation has as objective to examine the intrapopulational chromosome number variation in Z. sylvatica, from "caatinga" vegetation, in state of Pernambuco, Brazil.

\section{Material and methods}

All material was collected in population of plants located at Experimental Farm of "Empresa Brasileira de Pesquisa Agropecuária” (09¹8’15.45” S, 40²6’00” W) with a semiarid vegetation "caatinga", in Petrolina, state of Pernambuco, Brazil. Thirty four individuals were cultivated individually, in plastic pots, at experimental garden of Cytogenetic Laboratory at Departamento de Fitotecnia, Centro de Ciências Agrárias, Universidade Federal da Paraíba. For cytological analysis, young root tips were pretreated in 0,002 M 8-hydroxyquinoline at $4{ }^{\circ} \mathrm{C}$ for 4 hours, fixed in Carnoy's fixative 3:1 (ethanol: acetic acid) and stored at $-20^{\circ} \mathrm{C}$. Squashes were made in $45 \%$ acetic acid solution on glass slide, frozen with liquid nitrogen for removal of cover slips and stained with $2 \%$ Giemsa solution or $1 \%$ haematoxilin (Guerra \& Souza 2002). For counting and chromosome morphology, only entire cells and chromosomes with clearly visible centromere were considered. For centromere positions, was adopted terminology described for Guerra (1986) based on arm ratio and centromeric index from four cells in cytotypes with $2 n=12$ and $12+1 \mathrm{~B}$, except for triploid cytotype, which shows two spread cell with different condensation grade. In this case, the arm ratio and centromeric index is not presented. In table 1 are presented data of all chromosome pair individually. For count, each bulb were individually rooted in flask with water and observed a minimum of three cells by bulbs with spread chromosome.

For chromosome morphology the terminology suggested by Guerra (1986) was adapted: Metacentric (M), Submetacentric (Sm), Acrocentric (A) and Telocentric (T), based in arm ratios and centromeric index. After species identification, voucher material was deposited at Herbarium Prof. Jayme Coelho de Moraes (EAN). Cells best visualized were photographed with an Olympus D-54 digital camera adapted on an Olympus BX41 photomicroscope.

\section{Results and discussion}

Considering 32 individuals analyzed, 24 showed a somatic complement with $2 n=12$ chromosomes, five with $2 n=13$ and, three individuals with $2 n=18$ chromosomes. The $2 n=13$ karyotype was differentiated by a small supernumerary, submetacentric chromosome (about $3 \mathrm{~mm}$ ), visible in all metaphases. The record of $\mathrm{B}$ chromosomes in plants, in general, is relatively common (see, e.g. Cheng et al. 2000) as well as in genus Zephyranthes (Greizerstein \& Naranjo 1987). For Z. sylvatica, a cytotype with $2 n=12+1 \mathrm{~B}$ was previously observed by Guerra (2000) as Z. franciscana (actually a synonymous of $Z$. sylvatica), but none indication of plant source.

Reticulated interphase nuclei and chromosome complement formed by a larger metacentric pair of about 
$10 \mu \mathrm{m}$ long chromosomes, and other submetacentric and acrocentric five chromosomes pair with 7-5 $\mu \mathrm{m}$, were observed in all analyzed plants. The table 1 summarize the measure and chromosome patterns for cytotypes with $2 n=12,12+1 \mathrm{~B}$ and $2 n=18$. Cytotypes with $2 n=12$ and $2 n=12+1 \mathrm{~B}$ (figures $1,2,4,5$ ) showed chromosome polymorphism for the pairs 1 and 2, with one larger and another slightly smaller chromosome (11,59-10,15 and 9,32-8,05 $\mu \mathrm{m}$ respectively). In this case, the standard deviation on heteromorphic pairs was higher than others. Chromosome polymorphism also occurred in three individuals with $2 n=18$, with variation of the 17,5216,74 and $12,54-10,38 \mu \mathrm{m}$ respectively. This karyotype generally showed triplets formed by two homomorphic and one larger or smaller chromosomes (figures 3 and 6), especially visible in the triplets 1 and 2 . Chromosome numbers have been extensively used as a instrument to infer taxonomic and phylogenetic relations in plants (Guerra 2000), it is a generally stable character. However, in some groups, intraspecific numerical chromosome variations in different natural populations are common, mainly in bulbous plants as Urginea Kunth, (Talavera et al. 1995) or Ornithogalum tenuifolium Goiron (Hyacinthaceae) (Stedje 1989), and in plants with holocentric chromosomes as Carex (Dill.) L. (Cyperaceae) (Luceño 1993). In Amaryllidaceae, the record of $2 n=22$ and $2 n=33$ in Crinum zeylanicum L. (Wahlstrom \& Laane 1979), as well as interespecific differences of karyotype in various Crinum species, and report of $2 n=22$ and $2 n=22+1 \mathrm{~B}$ in a population of a Brazilian Hippeastrum species (Dutilh 1989), confirm numerical variability in this group.

In Zephyranthes intraspecific numerical chromosome variability, it was found in $Z$. aff. mesochloa Baker, with $2 n=12$ and $2 n=12+1 \mathrm{~B} ; Z$. brasiliensis, with $2 n=49$ and $49+1 \mathrm{~B} ;$ Z. grandiflora, with $67+1 \mathrm{~B}, \mathrm{Z}$. chlorozolen, with $72+1 B$ (Greizerstein \& Naranjo 1987), Z. candida with $2 n=38,40$ and 41 (Raina \& Khoshoo 1970) and in artificial hybrids (Flory \& Smith 1980b, Daviña 2001).

Among cytotypes, $2 n=12$ occurred in the majority of individuals of $Z$. sylvatica, indicating clearly that, this cytotype is the best adapted to local ecological conditions. Chromosome polymorphism observed in cytotypes with $2 n=12$ and $2 n=12+1 \mathrm{~B}$ hinders deduction of genomic

Table 1. Mean of chromosome measures in four cells in Zephyranthes sylvatica population in $2 n=12,12+1 \mathrm{~B}$ and $2 n=18$ cytotypes $(\mathrm{CP}=$ chromosome pair; $\mathrm{CL}=$ chromosome length; $\mathrm{AR}=$ arm ratio; $s=$ standard deviation; $\mathrm{CI}=$ chromosome Index).

\begin{tabular}{|c|c|c|c|c|c|c|c|c|c|c|c|c|}
\hline \multirow{3}{*}{$\frac{\mathrm{CP}}{1}$} & \multicolumn{4}{|c|}{$2 n=12$} & \multicolumn{4}{|c|}{$2 n=12+1 \mathrm{~B}$} & \multicolumn{4}{|c|}{$2 n=18$} \\
\hline & \multicolumn{2}{|c|}{$\mathrm{CL}(\mu \mathrm{m}) \pm s$} & \multirow{2}{*}{$\frac{\mathrm{AR}}{1,07}$} & \multirow{2}{*}{$\begin{array}{c}\mathrm{CI} \\
48,23\end{array}$} & \multicolumn{2}{|c|}{$\mathrm{CL}(\mu \mathrm{m}) \pm s$} & \multirow{2}{*}{$\frac{\mathrm{AR}}{1,17}$} & \multirow{2}{*}{$\frac{\mathrm{CI}}{45,93}$} & \multicolumn{2}{|c|}{$\mathrm{CL}(\mu \mathrm{m}) \pm s$} & \multirow{2}{*}{$\frac{\mathrm{AR}}{1,08}$} & \multirow{2}{*}{$\frac{\text { CI }}{47,87}$} \\
\hline & 11,59 & 1,01 & & & 9,32 & 0,96 & & & 17,52 & 1,18 & & \\
\hline 1 & 10,15 & & & 50,54 & 8,05 & & & 48,80 & 17,50 & & 1,03 & 49,10 \\
\hline 1 & & & & & & & & & 16,74 & & 1,04 & 48,95 \\
\hline 2 & & & 2,39 & 29,48 & 7,29 & 0,50 & 2,62 & 27,56 & 12,54 & 1,85 & 2,58 & 27,87 \\
\hline 2 & 7,97 & 0,82 & 2,06 & 32,59 & 6,59 & & 2,45 & 28,96 & 11,66 & & 2,58 & 27,87 \\
\hline 2 & 6,81 & & & & & & & & 10,38 & & 2,40 & 29,36 \\
\hline 3 & & & 1,77 & 35,97 & 6,63 & 0,15 & 1,64 & 37,75 & 10,95 & 0,67 & 1,73 & 36,55 \\
\hline 3 & 7,56 & 0,59 & 1,92 & 34,22 & 6,24 & & 1,58 & 38,62 & 10,06 & & 2,10 & 32,15 \\
\hline 3 & 6,72 & & & & & & & & 9,68 & & 2,27 & 30,57 \\
\hline 4 & & & 2,39 & 29,43 & 6,03 & 0,33 & 1,66 & 37,45 & 9,26 & 0,36 & 3,22 & 23,65 \\
\hline 4 & 6,01 & 0,14 & 2,51 & 28,45 & 6,10 & & 2,56 & 28,01 & 8,67 & & 4,13 & 19,48 \\
\hline 4 & 5,81 & & & & & & & & 8,25 & & 3,27 & 23,37 \\
\hline 5 & & & 3,30 & 23,25 & 5,64 & 0,15 & 3,68 & 21,32 & 8,50 & 0,60 & 2,55 & 28,11 \\
\hline 5 & 5,59 & 0,52 & 3,04 & 24,74 & 5,08 & & 2,80 & 26,30 & 7,07 & & 3,18 & 23,90 \\
\hline 5 & 4,85 & & & & & & & & 7,51 & & 3,05 & 24,68 \\
\hline 6 & & & 2,82 & 26,16 & 4,82 & 0,07 & 2,06 & 32,58 & 7,05 & 0,68 & 3,21 & 23,74 \\
\hline 6 & 4,93 & 0,19 & 2,42 & 29,17 & 4,35 & & 2,54 & 28,19 & 6,04 & & 2,32 & 30,04 \\
\hline 6 & 5,21 & & & & & & & & 5,62 & & 1,96 & 33,77 \\
\hline B & & & & & 2,87 & & 1,76 & 36,14 & & & & \\
\hline
\end{tabular}



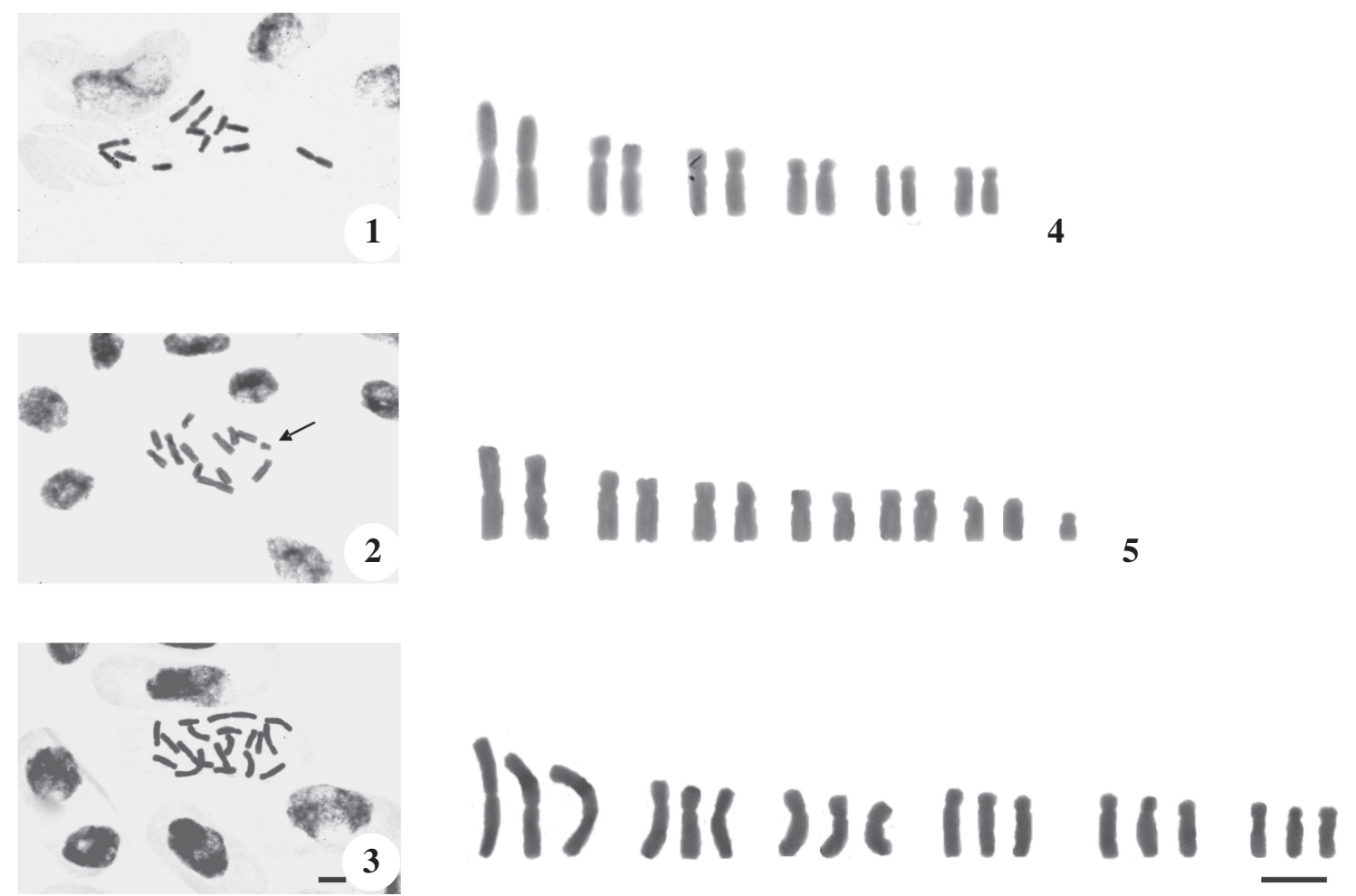

6

Figures 1-6. Mitotic metaphases and karyotypes of Zephyranthes sylvatica. Mitotic metaphase with $2 \mathrm{n}=12(1), 2 \mathrm{n}=12+$ 1B (2), $2 \mathrm{n}=18$ (3) and respective karyotypes (4, 5 and 6). In 4 and 5, heteromorphism in pairs 1 and 2; is sholon 4 chromosome in 2 (arrow) and 5, and heteromorphism in triplets 1 and 2 in the triploid cytotype (6). Bar 10 $\mu$.

structure of the B chromosome in Z. sylvatica. In Secale cereale the genomic structure of supernumerary chromosomes, studied with in situ hybridization suggested that they were formed partially by a similar genome of the A chromosomes, besides specific terminal heterocromatin B (Tsujimoto \& Niwa 1992). These chromosomes were positively associated with genome size, especially in dicots, and slightly negatively associated with ploidy level (Trivers et al. 2004). The record of 32-38 pg 1C value of DNA in two species of Zephyranthes indicate a large DNA amount in this genus (Zonneveld et al. 2005) probably enhancing the occurrence of B chromosomes in this genus.

The cytotypes with $2 n=18$ suggest what the occurrence of triploid individuals in the studied population is well established. Nevertheless, field observations have not allowed distinction of morphotypes that could be related to triploid condition, suggesting an autotriploid origin for these individuals. However, in some species of Zephyranthes with chromosome polymorphism allopolyploid origin cannot be discarded (Daviña \& Fernández 1989). Autopolyploids generally are originated by accidental formation of unreduced gametes which, after fertilization with normal gametes, could originate triploid forms (Stebbins 1971, Grant 1989). The occurrence of three triploid individuals in a universe of 32 analyzed plants suggests that autotriploids may be relatively frequent in this population. Probably the sterility in those hybrids could be contoured through agamic reproduction as in Z. brasiliensis (Traub) Traub (Greizertein \& Naranjo 1987). According to Dyer (1967) in Nothoscordum gracile (Ailton) Stearn (as N. fragrans Kunth) (Alliaceae), a structural heterozygote with $2 n=19$, sterility has been bypassed by an extensive and conjunct production of adventitious and sexual embryos. Although traditionally considered uncommon in nature (Grant 1989) more recent data indicate that autopolyploidy seems be more frequent (revised by Soltis et al. 2003), with major importance for chromosome number multiplication in plants.

Acknowledgements - Authors are grateful to EmbrapaSemi-árido for permission to collect material and Luciana Cordeiro do Nascimento by suggestions and correction, of English version.

\section{References}

ARROYO, S.C. 1981. Systematic, anatomical studies on Amaryllidaceae, including morphological cytological and phytogeographical considerations. PhD Thesis, University of Reading, Reading. 
CHENG, Z.K., YU, H.X., YAN, H.H. \& GU, M.H. 2000. B chromosome in a rice aneuploid variation. Theoretical and Applied Genetics 101:564-568.

DAVIÑA, J.R. 2001. Estudios citogeneticos en algunos generos argentinos de Amaryllidaceae. Tese de doutorado, Universidade Nacional de Cordoba, Cordoba.

DAVIÑA, J.R. \& FERNÁNDEZ, A. 1989. Karyotype and meiotic behavior in Zephyranthes (Amaryllidaceae) from South America. Cytologia 54:269-274.

DUTILH, J.H.A. 1989. Morphological variation in a population of Hippeastrum Herb. Herbertia 45:152-155.

DYER, A.E. 1967. The maintenance of structural heterozygosity in Nothoscordum fragans Kunth. Carylogia 20:287-308.

FELIX, L.P. \& GUERRA, M. 2000. Cytogenetics and cytotaxonomy of some Brazilian species of Cymbidioid orchids. Genetics and Molecular Biology 23:957-978.

FELIX, L.P. \& GUERRA, M. 2005. Basic chromosome number of terrestrial orchids. Plant Systematics and Evolution 254:131-148.

FLORY, W.S. 1977. Overview of chromosome evolution in the Amaryllidaceae. The Nucleus 20:70-88.

FLORY, W.S. \& SMITH, G.L. 1980a. High chromosome number in several Zephyrantheae taxa. Plant Life 36: 63-72.

FLORY, W.S. \& SMITH, G.L. 1980b. The chromosomes of Habranthus martinezii, $H$. robustus, and their $\mathrm{F}_{1}$ hybrid. Plant Life 36:54-62.

GRANT, V. 1989. Especiación Vegetal. 1aㅡ ed. Versión española: E.C. Herre y H.E.D. Garcia. Noriega Editores, México.

GREIZERSTEIN, E.J. \& NARANJO, C.A. 1987. Estudios cromosomicos en especies de Zephyranthes (Amaryllidaceae). Darwiniana 29:169-186.

GUERRA, M.S. 1986. Reviewing the chromosome nomenclature of Levan et al. Revista Brasileira de Genética 9:741-743.

GUERRA, M. 2000. Chromosome number variation and evolution in monocots. In: Monocots: Systematics and Evolution (K.L. Wilson \& D.A. Morrison, eds.). CSIRO publishing, Collingwood, p.127-136.

GUERRA, M. \& NOGUEIRA, M.T.M. 1990. The cytotaxonomy of Emilia spp. (Asteraceae: Senecioneae) occurring in Brazil. Plant Systematic Evolution 170: 229-236

GUERRA, M., SANTOS, K.G.B., SILVA, E.B. \& EHRENDORFER, F. 2000. Heterochromatin banding patterns in Rutaceae - Aurantioideae - a case of parallel chromosomal evolution. American Journal of Botany 87:735-747.

GUERRA, M. \& SOUZA, M.J. 2002. Como observar cromossomos: Um guia de técnicas em citogenética vegetal, animal e humana. Funcec - Editora, Recife.

HUTCHINSON, J. 1959. The families of flowering plants. Clarendon Press, Oxford.
JUDD, W.S., CAMPBELL, C.S., KELlOGG, E.A. \& STEVENS, P.F. 1999. Plant Systematics: a phylogenetic approach. Sinauer Associates, Massachusetts.

LUCEÑO, M. 1993. Chromosome studies on Carex L. section Mitratae Kükenth. (Cyperaceae) in the Iberian Peninsula. Cytologia 58:321-330.

MEEROW, A.W., FAY, M.F., CHASE, M.W., GUY, C.L., LI, Q., SNIJMAN, D. \& YANG, S. 2000a. Phylogeny of Amaryllidaceae: molecules and morphology. In: Monocots: systematics and evolution (K.L. Wilson \& D.A. Morrison, eds.). CSIRO publishing, Collingwood, p.372-386.

MEEROW, A.W., GUY, C.L., LI, Q. \& YANG, S. 2000 b. Phylogeny of the American Amaryllidaceae based on nrDNA ITS sequences. Systematic Botany 25:708-726.

MELO, N.F., CERVI, A.C. \& GUERRA, M. 2001. Karyology and cytotaxonomy of the genus Passiflora L. (Passifloraceae). Plant Systematics and Evolution 226:69-84.

NARANJO, C.A. 1969. Cariotipos de nueve especies argentinas de Rhodophiala, Hippeastrum, Zephyranthes y Habranthus (Amaryllidaceae). Kurtziana 5:67-87.

NARANJO, C.A. 1974. Karyotypes of four Argentine species of Habranthus and Zephyranthes (Amaryllidaceae). Phython 32:61-71.

RAINA, S.N. \& KHOSHOO, T.N. 1970. Cytogenetics of tropical bulbous ornamentals VI: chromosomal polymorphism in cultivated Zephyranthes. Caryologia 2:217-227.

SOLTIS, D.E., SOLTIS, P.S. \& TATE, J.A. 2003. Advances in the study of polyploidy since plant speciation. New Phytologist 161:173-191.

STEDJE, B. 1989. Chromosome evolution within the Ornithogalum tenuifolium complex (Hyacinthaceae), with special emphasis on the bimodal karyotypes. Plant Systematic and Evolution 166:79-89.

STEBBINS, G.L. 1971. Chromosomal evolution in higher plants. Edward Arnold, London.

TALAVERA, S., ORTIZ, P.L., ARISTA, M. \& BASTIDA, Y.F. 1995. Estudio cariosistematico de algunas monocotiledoneas bulbosas de Marruecos. Lagascalia 18:83-104.

TRIVERS, R., BURT, A. \& PALESTIS, B.G. 2004. B chromosome and genome size in flowering plants. Genome 47:1-8.

TSUJIMOTO, H. \& NIWA, K. 1992. DNA structure of the $\mathrm{B}$ chromosome of rye revealed by in situ hybridization using repetitive sequences. Japan Journal Genetic 67: 233-241.

WAHLSTROM, R. \& LAANE, M.M. 1979. Chromosome analyses in African Crinum species (Amaryllidaceae). Hereditas 91:183-206.

ZONNEVELD, B.J.M., LEITCH, I.J. \& BENNET, M.D. 2005. First nuclear amount in more than 300 angiosperms. Annals of Botany 96:229-244. 